\title{
PROFESSOR CHARLES AMBROSE STOREY
}

Charles Ambrose Storey, a Fellow of this Society since 1915, died at his home in Hove on 24th April, 1967. Born at Blackhill, Durham, on 21st August, 1888, he was educated at Rossall and at Trinity College, Cambridge, of which he was a Major Scholar. After a brilliant academic career, first in Classics and then in Oriental Languages, he was appointed Professor of Arabic in 1914 at the Anglo-Mohamedan Oriental College (now the Muslim University) of Aligarh, India, which he left in 1919 to become Assistant Librarian to the India Office. He was made Librarian in 1927 and was elected Sir Thomas Adams Professor of Arabic at Cambridge in 1933 - a position which he held until his retirement in 1947.

His publications include an edition of the Fäkhir of al-Mufaddal ibn Salamah (1915), Catalogue of the Arabic manuscripts in the India Office Library, Vol. II, Part i (1930), and various articles and reviews; but he will be best remembered for his invaluable and monumental work Persian literature: A bio-bibliographical survey, which, as he remarked in the preface to the first section, published in 1927, was intended to be the counterpart to Brockelmann's Geschichte der arabischen Litteratur. Since Storey was above all a librarian and bibliographer, he devoted his immense learning to this project for the greater part of his life. The last section published appeared in 1958. It was originally his intention to leave instructions in his will that the portion of Persian literature which remained unpublished at his death should be destroyed but, happily for Orientalism, he changed his mind.

Professor Storey was a bachelor, quiet and sensitive, wholly immersed in his work but kind and encouraging to those of his students who were keen to succeed in their chosen field. Shy and somewhat unsociable even at the best of times, he became in his later years a complete recluse, seldom leaving his house except to take his meals at a restaurant. Most of his days seem to have been spent in learning Russian and following the progress of his numerous investments.

Apart from a few small legacies, he left all his estate to the Society, including holdings to the value of about $£ 20,000$, his house in Lawrence Road, Hove, his fine library, and the unpublished portion of his Persian literature-a large amount of material in files and boxes of index cards which is now being examined with a view to publication by the Society at some future date.

G. M. MEREDITH-OWENS. 